\title{
Determination of Critical Limit of Zinc for Rice (Oryza sativa L.) and Potato (Solanum tuberosum L.) Cultivation in Floodplain Soils of Bangladesh
}

\author{
Mamunur Rahman ${ }^{1}$, Mohammad Mofizur Rahman Jahangir ${ }^{1}{ }^{(1)}$, Mohammad Golam Kibria ${ }^{1}$, \\ Mahmud Hossain ${ }^{1} \mathbb{D}$, Md Hosenuzzaman ${ }^{1} \mathbb{D}$, Zakaria M. Solaiman ${ }^{2} \mathbb{D}$ and Md Anwarul Abedin ${ }^{1, *(\mathbb{D})}$ \\ 1 Department of Soil Science, Faculty of Agriculture, Bangladesh Agricultural University, \\ Mymensingh 2202, Bangladesh; mamunur76@yahoo.com (M.R.); mmrjahangir@bau.edu.bd (M.M.R.J.); \\ kibria.ss@bau.edu.bd (M.G.K.); mahmud.ss@bau.edu.bd (M.H.); hosen.ss@bau.edu.bd (M.H.) \\ 2 UWA School of Agriculture and Environment, The University of Western Australia, \\ Perth, WA 6009, Australia; zakaria.solaiman@uwa.edu.au \\ * Correspondence: m.a.abedin@bau.edu.bd; Tel.: +880-1718031462
}

Citation: Rahman, M.; Jahangir, M.M.R.; Kibria, M.G.; Hossain, M.; Hosenuzzaman, M.; Solaiman, Z.M.; Abedin, M.A. Determination of Critical Limit of Zinc for Rice (Oryza sativa L.) and Potato (Solanum tuberosum L.) Cultivation in Floodplain Soils of Bangladesh. Sustainability 2022, 14, 167. https://doi.org/10.3390/su14010167 Academic Editor: Franco Ajmone Marsan

Received: 16 November 2021 Accepted: 22 December 2021 Published: 24 December 2021

Publisher's Note: MDPI stays neutral with regard to jurisdictional claims in published maps and institutional affiliations.

Copyright: (c) 2021 by the authors. Licensee MDPI, Basel, Switzerland. This article is an open access article distributed under the terms and conditions of the Creative Commons Attribution (CC BY) license (https:// creativecommons.org/licenses/by/ $4.0 /)$.

\begin{abstract}
The critical limit for zinc (Zn) varies from 0.38 to $2 \mu \mathrm{g} / \mathrm{g}$ soil depending on the crop and soil type. However, the critical limit for $\mathrm{Zn}$ was not explored recently for rice and potato cultivation in the floodplain soils of Bangladesh. A pot experiment was conducted to determine the critical limits of $\mathrm{Zn}$ in soil and plants for rice and potato cultivation in two agro-ecological zones (AEZs) of Bangladesh. The soil samples were collected from 20 different locations of Old Brahmaputra and Active Ganges Floodplains with low $(<0.9 \mu \mathrm{g} / \mathrm{g})$, medium $(0.91-1.80 \mu \mathrm{g} / \mathrm{g})$ and high $(>1.80 \mu \mathrm{g} / \mathrm{g}) \mathrm{Zn}$ status. The experiment was laid out in a factorial and completely randomized design with two levels of $\mathrm{Zn}\left(\mathrm{Zn}_{0}\right.$ and $\mathrm{Zn}_{1}(0$ and $4.87 \mathrm{~kg} / \mathrm{ha}$ as $\mathrm{Zn}$ sulphate) ) applied to 20 different soil samples for rice and potato cultivation using three replications. The critical limit of $\mathrm{Zn}$ was determined through a graphical and statistical approach and crops were harvested at the stem elongation (for rice) and tuber filling (for potato) stage. The critical limit of $\mathrm{Zn}$ in soil for rice was found to be 0.8 and $0.85 \mu \mathrm{g} / \mathrm{g}$ by graphical and statistical methods, respectively, and both methods revealed the same value $(0.73 \mu \mathrm{g} / \mathrm{g})$ for potato. The critical limit of $\mathrm{Zn}$ in rice plants was 23.9 and $24.32 \mu \mathrm{g} / \mathrm{g}$, whereas in potato plants it was 27.1 and $26.61 \mu \mathrm{g} / \mathrm{g}$, determined by graphical and statistical methods, respectively. The added $\mathrm{Zn}$ supply in soil significantly increased the dry matter accumulation in rice (by $5.6 \%$ ) and potato (by $10 \%$ ) compared to no $\mathrm{Zn}$ supply. Therefore, a significant positive response to added $\mathrm{Zn}$ could be observed on crop growth and yield when the $\mathrm{Zn}$ concentration remained below the mentioned critical level for rice and potato cultivation in floodplain soils of Bangladesh.
\end{abstract}

Keywords: macronutrients; critical limits; floodplain soils; agro-ecological zones

\section{Introduction}

Zinc is an essential micronutrient for plant growth and development [1]. It performs a significant role in several plant metabolic processes, such as enzyme activity, chlorophyll formation, photosynthesis, respiration, the buildup of the cell wall and other biochemical functions [2,3]. Its importance in crop production is similar to that of other essential nutrients, as plants will not complete their life cycle without an adequate supply of $\mathrm{Zn}$ [4]. Zinc deficiency in cereal plants, including rice, is a severe problem that causes reduced agricultural productivity worldwide [1]. Zinc deficiency in crops reduces grain yield and hampers nutritional quality. Zinc deficiency was reported in the soils of lowland rice cultivation in Bangladesh, India, Pakistan, Philippines, Myanmar, Indonesia, Japan, Korea, Taiwan and Thailand [5]. Zinc was first reported as deficient in Bangladesh soil in 1982 [6]. Currently, an area of 2.76 million ha in Bangladesh has Zn deficiency in soils [7].

Rice (Oryza sativa) is one of the most important food crops and staple food for more than one-third of the world's population [8,9]. In Bangladesh, rice is the main component 
of the daily diet. Considering cultivable land in Bangladesh, the most significant area is used for rice cultivation (11.68 million ha). It occupies the third position in the world for rice production (37.36 million $\mathrm{MT}$ ), behind China and India. On the other hand, potato (Solanum tuberosum) is one of the most important crops cultivated globally [10] and the source of many essential compounds (starch, proteins, vitamins, sugars, minerals and other useful substances) in the human diet [11,12]. Potato, a staple food in many countries, is an important crop in Bangladesh, cultivated on $1.09 \mathrm{M}$ ha. The adequate application of $\mathrm{Zn}$ is important along with all other essential nutrients to increase the growth and yield of potatoes. Thus, it is essential to identify specific nutrients in the soil below which the crop shows significant deficiency symptoms. The farmers will know the requirements of fertilizer application for a sustainable agricultural production system, especially for rice and potato.

Critical limit (CL) determines a threshold value of a nutrient in the soil, below which the crop will readily respond to its application. The critical limit of a nutrient in a plant refers to the level at or below which plants either develop deficiency symptoms, or there is a decrease in crop yields compared to optimum yields. The concept of CL of nutrients was introduced by Ulrich [13] and Smith [14]. However, the graphical method [15], and later the statistical approach [16], are being widely used to establish the CL of a nutrient. Importantly, there is no comparative report between these two approaches to determining CL in soil and plants in the floodplain soils of Bangladesh. Critical limits in soils and plants help in making practical recommendations to specific crops in a typical soil. Hence, the situation justifies the need to adjudicate and update the critical limit of different plant nutrients to formulate an optimum fertilizer dose for deficient nutrients in different crops and soils, in order to achieve a satisfactory crop yield. Therefore, it is essential to determine the CL for $\mathrm{Zn}$ in soil and plants to make Zn applications more efficient and rational for rice and potato cultivation in Bangladesh.

The present study focused on evaluating the CL for $\mathrm{Zn}$ in soil and plant for sustainable rice and potato cultivation in the floodplain soils of Bangladesh. Furthermore, this study will compare the graphical and statistical approaches to determining the CL for Zn in soil and plants for rice and potato predominantly growing in the floodplain soils of Bangladesh.

\section{Materials and Methods}

\subsection{Soil Collection, Analysis and Test Crop}

A total of 720 soil samples (topsoil: $0-15 \mathrm{~cm}$ soil depth) were collected from two agro-ecological zones (AEZs) of Bangladesh, representing floodplain soils (AEZ 9: Old Brahmaputra Floodplain and AEZ 9: Active Ganges Floodplain). The AEZs were developed mainly based on the soil characteristics and climatic conditions, and Bangladesh was divided into $30 \mathrm{AEZs,} \mathrm{where} \mathrm{rice} \mathrm{and} \mathrm{potato} \mathrm{are} \mathrm{predominantly} \mathrm{grown} \mathrm{in} \mathrm{floodplain} \mathrm{soils.}$ All soils were air-dried, sieved $(\leq 2 \mathrm{~mm})$ and mixed until homogenous. The collected soil samples were analyzed to determine the different physico-chemical properties of soil such as texture, $\mathrm{pH}$, electrical conductivity, organic matter and soil Zn status following standard methods [17]. The physico-chemical properties of the collected soil samples measured before starting the experiments are presented in Table 1.

Based on the $\mathrm{Zn}$ status in the collected soil samples, we selected 20 soil samples, comprising four high $(>1.80 \mu \mathrm{g} / \mathrm{g})$, four medium $(0.91-1.80 \mu \mathrm{g} / \mathrm{g})$ and $12 \mathrm{low}(<0.9 \mu \mathrm{g} / \mathrm{g})$ $\mathrm{Zn}$-containing soils. These soils were used for conducting the pot experiments under glasshouse conditions. The non-draining plastic pots ( $4 \mathrm{~kg}$ capacity) were prepared with $3 \mathrm{~kg}$ of the collected soil samples for growing crops. Rice (var. BRRI dhan88) and potato (var. BARI Alu-7: Diamond) were used as test crops in this study. 
Table 1. Selected soil properties of the collected soil samples before starting the experiment.

\begin{tabular}{cccccc}
\hline Soil Sample No. & $\begin{array}{c}\text { Textural Class } \\
\text { (USDA) }\end{array}$ & $\mathbf{p H}$ & $\mathbf{E C ~ ( d S / m )}$ & $\begin{array}{c}\text { Organic } \\
\text { Matter (\%) }\end{array}$ & Zn $(\boldsymbol{\mu g} / \mathbf{g})$ \\
\hline 1 & Loam & 6.83 & 0.14 & 0.82 & 0.16 \\
2 & Silt Clay Loam & 7.08 & 0.13 & 1.50 & 0.24 \\
3 & Silt Loam & 6.89 & 0.24 & 1.10 & 0.28 \\
4 & Silt Loam & 7.46 & 0.12 & 1.74 & 0.38 \\
5 & Silt Loam & 5.51 & 0.07 & 1.91 & 0.40 \\
6 & Loam & 5.67 & 0.11 & 1.5 & 0.46 \\
7 & Sandy Loam & 7.25 & 0.11 & 1.34 & 0.52 \\
8 & Silt Loam & 6.88 & 0.16 & 1.34 & 0.68 \\
9 & Loam & 7.48 & 0.12 & 1.00 & 0.70 \\
10 & Silt Loam & 5.26 & 0.07 & 2.86 & 0.75 \\
11 & Silt Loam & 6.50 & 0.13 & 1.63 & 0.82 \\
12 & Silt Clay Loam & 6.12 & 0.08 & 3.91 & 0.92 \\
13 & Silt Loam & 5.78 & 0.07 & 2.59 & 0.94 \\
14 & Silt Loam & 6.33 & 0.04 & 1.48 & 1.34 \\
15 & Silt Loam & 5.25 & 0.06 & 2.86 & 1.35 \\
16 & Loam & 6.00 & 0.08 & 1.62 & 2.24 \\
17 & Clay loam & 5.20 & 0.10 & 3.81 & 2.78 \\
18 & Silt Loam & 5.27 & 0.11 & 2.72 & 2.81 \\
19 & Silt Loam & 7.34 & 0.16 & 1.60 & 3.17 \\
20 & Silt Loam & 7.16 & 0.14 & 1.41 & $0.16-3.17$ \\
Range & - & $5.20-7.48$ & $0.04-0.24$ & $0.82-3.91$ & 1.08 \\
Mean & -6.36 & 0.11 & 1.94 & \\
\hline
\end{tabular}

\subsection{Experimental Design and Approach}

This study was conducted during winter (2019-2020) in the net-house of Department of Soil Science, Bangladesh Agricultural University, Bangladesh. The two-factorial experiment consisted of two levels of $\mathrm{Zn}$ for each plant species ( 0 and $4.87 \mathrm{~kg} / \mathrm{ha})$, rice and potato, and 20 selected soil samples collected from different AEZs with varying available $\mathrm{Zn}$ (ranging from 0.16 to $3.17 \mu \mathrm{g} / \mathrm{g}$ soil). The treatments were replicated three times using completely randomized design (six pots $(2 \mathrm{Zn}$ rates $\times 3$ replication) for each soil and 120 pots ( 6 pots $\times 20$ soils) for each crop). All soils were amended with the following basal nutrients (in $\mathrm{mg} / \mathrm{kg}$ soil) mixed through the entire soil volume in each pot before sowing: $\mathrm{N}$ (150) from urea, $\mathrm{P}$ (25) from triple superphosphate, $\mathrm{K}(80)$ from muriate of potash and $\mathrm{B}$ (1) from boric acid. Analytical grade $\mathrm{Zn}$ sulphate $\left(\mathrm{ZnSO}_{4} \cdot 2 \mathrm{H}_{2} \mathrm{O}\right)$ was used as the source of $\mathrm{Zn}$ for soil application.

This experiment was conducted in winter (November 2019 to February 2020) with an average day length of $11 \mathrm{~h}$ and temperature of $22{ }^{\circ} \mathrm{C}$. Initially, four seedlings and a $45 \mathrm{~g}$ seed of potato was planted in each pot for rice and potato, respectively. After two weeks, rice seedlings were thinned by removing two seedlings from four. The pots were watered as per requirement; weeding and other intercultural operations were carried out as and when required. The plants were cut at the stem elongation stage for rice (76 days) and tuber filling stage for potato (45 days), washed with distilled water and dried in an oven at $65^{\circ} \mathrm{C}$ for $48 \mathrm{~h}$ for recording dry biomass yield. Dried plant samples from each pot were grinded separately using a stainless still grinder. After that, the ground plant samples were digested in a mixture of 10:4:1 of $\mathrm{HNO}_{3}: \mathrm{HClO}_{4}: \mathrm{H}_{2} \mathrm{SO}_{4}$ on a hot plate and filtered by Whatman no. 42 to estimate $\mathrm{Zn}$ by atomic absorption spectrophotometer [18].

\subsection{Critical Limit Determination by Graphical and Statistical Approaches}

The graphical method of determining CL for $\mathrm{Zn}$ was followed as described by Cate and Nelson [15]. In this procedure, a scatter diagram of the relative yields (Bray's percent DM yield) as $y$-axis versus soil test values as $x$-axis was plotted. Bray's percent DM yield was determined via the following equation.

Bray's \% dry matter $(\mathrm{DM})$ yield $=(\mathrm{DM}$ yield without $\mathrm{Zn}$ treatment $/ \mathrm{DM}$ yield with $\mathrm{Zn}$ treatment) $\times 100$

The CL for $\mathrm{Zn}$ was also determined following a statistical approach as described by Cate and Nelson [16]. By this simple iterative process, a series of $R^{2}$ values could be 
obtained for divisions made at various $\mathrm{Zn}$ levels. The critical level of $\mathrm{Zn}$ was determined from $R^{2}$ values where it was maximum.

\subsection{Statistical Analysis}

The raw data observed from pot experiments were analyzed using two factorial complete randomized design (CRD) to draw the valid differences among the treatments and soils. The data were subjected to two-way ANOVA and the significance of treatment on dry matter yield, concentration, and uptake of $\mathrm{Zn}$ by rice and potato plants was tested as described by Gomez and Gomez [19].

\section{Results}

\subsection{Dry Matter Accumulation of Rice and Potato}

The data of dry matter of plant biomass (g/pot) of rice plants grown at low-, mediumand high-Zn-status soils, as influenced by $\mathrm{Zn}$ application with $\mathrm{Zn}_{0}$ and $\mathrm{Zn}_{4.87}$, are presented in Table 2. The results demonstrated that the most significant, highest dry matter yield (g/pot) was found in high $\mathrm{Zn}$ status soils $(26.53 \mathrm{~g} / \mathrm{pot})$ as compared to medium (20.33 g/pot) and low (14.96 g/pot) Zn status soils. The dry matter accumulation (g/pot) of rice plants was found to increase significantly due to the application of $4.87 \mathrm{~kg} \mathrm{ZnSO}_{4} \cdot 7 \mathrm{H}_{2} \mathrm{O}$ per hectare (21.17 g/pot) over control (20.04 g/pot). The interaction effect between $\mathrm{Zn}$ status (low, medium and high) and treatment $\left(\mathrm{Zn}_{0}\right.$ and $\left.\mathrm{Zn}_{4.87}\right)$ was non-significant with respect to the dry matter yield of rice plant.

Table 2. Effect of $\mathrm{Zn}$ application on dry matter yield (g/pot) of rice and potato on low-, medium- and high-Zn-containing soils in response to $\mathrm{Zn}$ amendment.

\begin{tabular}{ccc}
\hline & Dry Matter Yield of Rice (g/pot) & Dry Matter Yield of Potato (g/pot) \\
\hline Zn Status & \\
\hline Medium & 14.96 & 4.20 \\
\hline High & 20.33 & 5.59 \\
\hline $\mathrm{SE} \pm$ & 26.53 & 6.09 \\
\hline $\mathrm{CD} @ 5 \%$ & 0.61 & 0.16 \\
\hline & 1.21 & 0.31 \\
\hline $\mathrm{Zn} \mathrm{n}_{0}$ & Treatment $(\mathrm{T})$ & 5.04 \\
\hline $\mathrm{Zn} \mathrm{n}_{4.87}$ & 20.04 & 5.55 \\
\hline $\mathrm{SE} \pm$ & 21.17 & 0.12 \\
\hline $\mathrm{CD} @ 5 \%$ & 0.49 & 0.25 \\
\hline & 0.96 & \\
\hline $\mathrm{SE} \pm$ & Interaction $(\mathrm{Zn} \times \mathrm{T})$ & 0.19 \\
\hline $\mathrm{CD} @ 5 \%$ & 0.7513 & $\mathrm{NS}$ \\
\hline
\end{tabular}

The interaction between Zn-status soils and levels of Zn on potato dry matter was found to be non-significant. Applying Zn significantly increased the dry matter yield in potatoes in most of the cases of this experiment (Table 2). The addition of $\mathrm{Zn}(4.87 \mathrm{~kg} / \mathrm{ha})$ increased dry matter yield (5.55 g/pot) compared to control $(5.04 \mathrm{~g} / \mathrm{pot})$, as shown in Table 2. The high-Zn-status soils obtained a significantly higher dry matter yield (6.09 g/pot), followed by medium-Zn-status (5.59 g/pot).

\subsection{Critical Limits of $\mathrm{Zn}$ in Soil and Plant for Rice}

The critical limit of available Zn (DTPA extractable) for rice in soil was found to be $0.85 \mu \mathrm{g} / \mathrm{g}$ by a statistical method (Table S1) and $0.8 \mu \mathrm{g} / \mathrm{g}$ by a graphical method (Figure 1). 
The Zn available in the soil (DPTA extractable) was arranged in ascending order (P1) and then Bray's percent was reported to the respective available Zn status of the soil. The mean relative yield in P1, correlated sum of squares of deviation from the mean of P2 (CSS-I), the mean relative yield in $\mathrm{P} 2$, and the correlated sum of squares of deviation from mean of P2 (CSS-II) were calculated. From the highest $\mathrm{R}^{2}(0.871)$ the postulated critical limit of $\mathrm{Zn}$ for rice was found as $0.85 \mu \mathrm{g} / \mathrm{g}$ of $\mathrm{Zn}$ available in the soil.

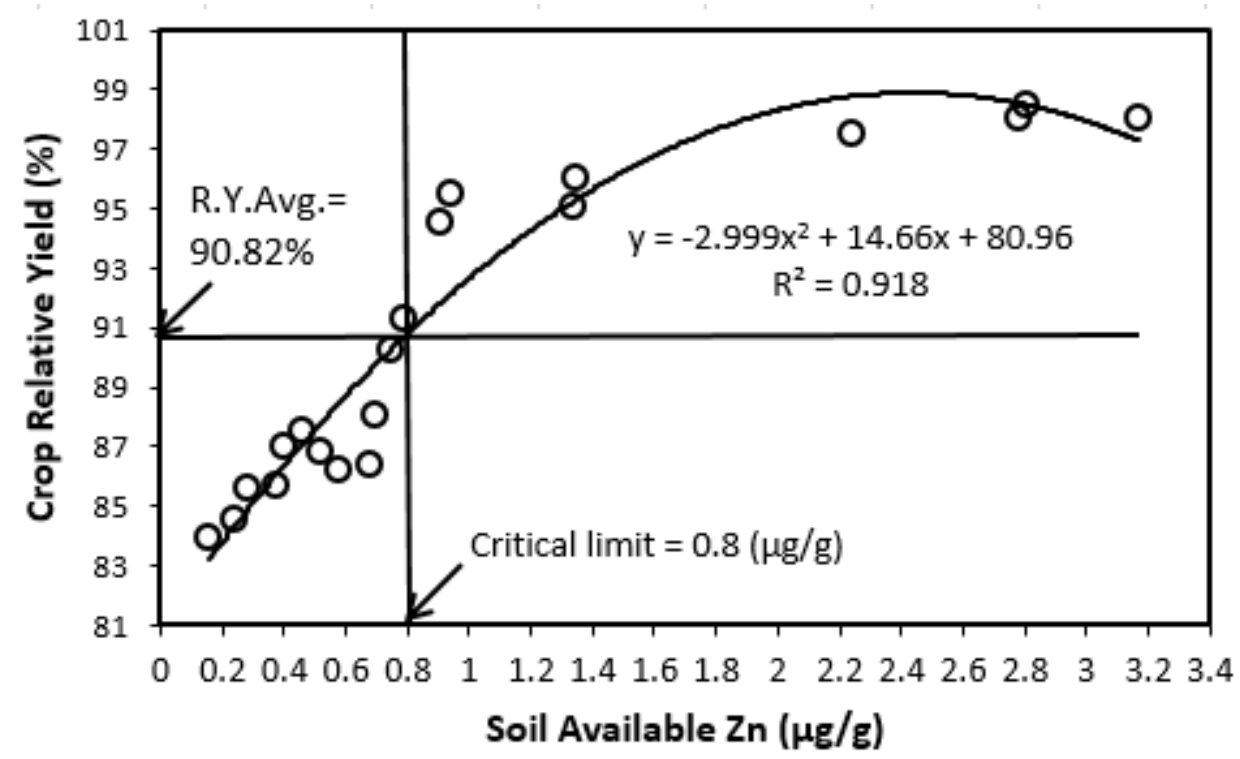

Figure 1. Scatter diagram of available soil Zn vs. Bray's percent dry matter yield of rice.

The critical limit of $\mathrm{Zn}$ for rice in plants was estimated by arranging the $\mathrm{Zn}$ concentration in ascending order. Therefore, the Bray's percent dry matter yield was reported for the respective values of $\mathrm{Zn}$ concentration in rice plants. The values of the mean relative yield in P1, corrected sum of squares of deviations from mean of P1 (CSS-I), mean relative yield in P2 and corrected sum of squares of deviations from mean P2 (CSS-II) were calculated. From these data, $\mathrm{R}^{2}$ values were calculated for every concentration of $\mathrm{Zn}$ in rice plants. The postulated critical limit of $\mathrm{Zn}$ in rice plants was found to be 24.32 and $23.9 \mu \mathrm{g} / \mathrm{g}$ by graphical (Figure 2) and statistical methods (Table S2).

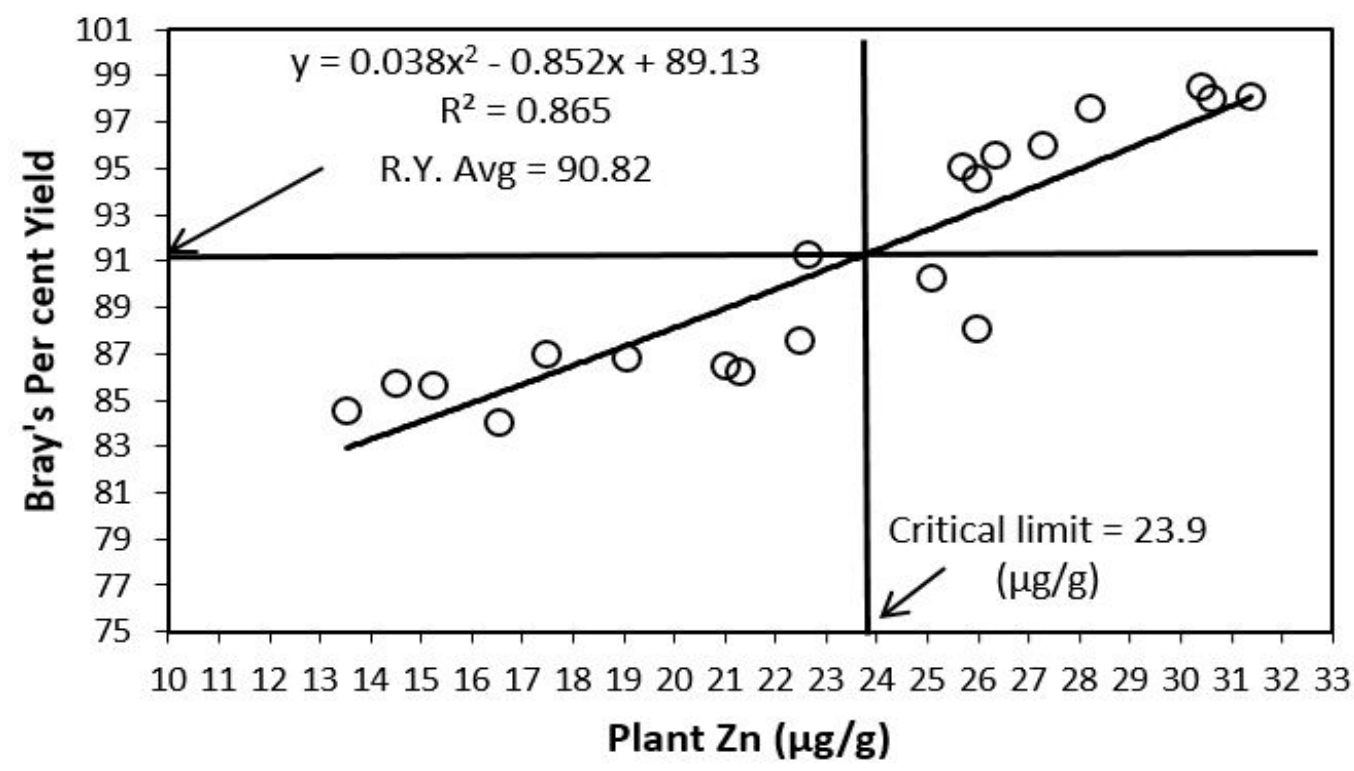

Figure 2. Scatter diagram of Zn concentration in plant vs. Bray's percent dry matter yield of rice. 


\subsection{Critical Limits of $\mathrm{Zn}$ in Soil and Plant for Potato}

The data of dry matter of plant biomass (g/pot) and Bray's percent yield of potato were utilized for evaluating the critical limit of soil and plant Zn for potato (Tables S3 and S4). The scatter diagram with soil-available Zn vs. Bray's percent yield in potato are depicted in Figure 3 for the graphical method and the postulated critical limit shown in Table S3 for the statistical method is $7.3 \mu \mathrm{g} / \mathrm{g}$, indicating the critical limit of $\mathrm{Zn}$ in soil, respectively.

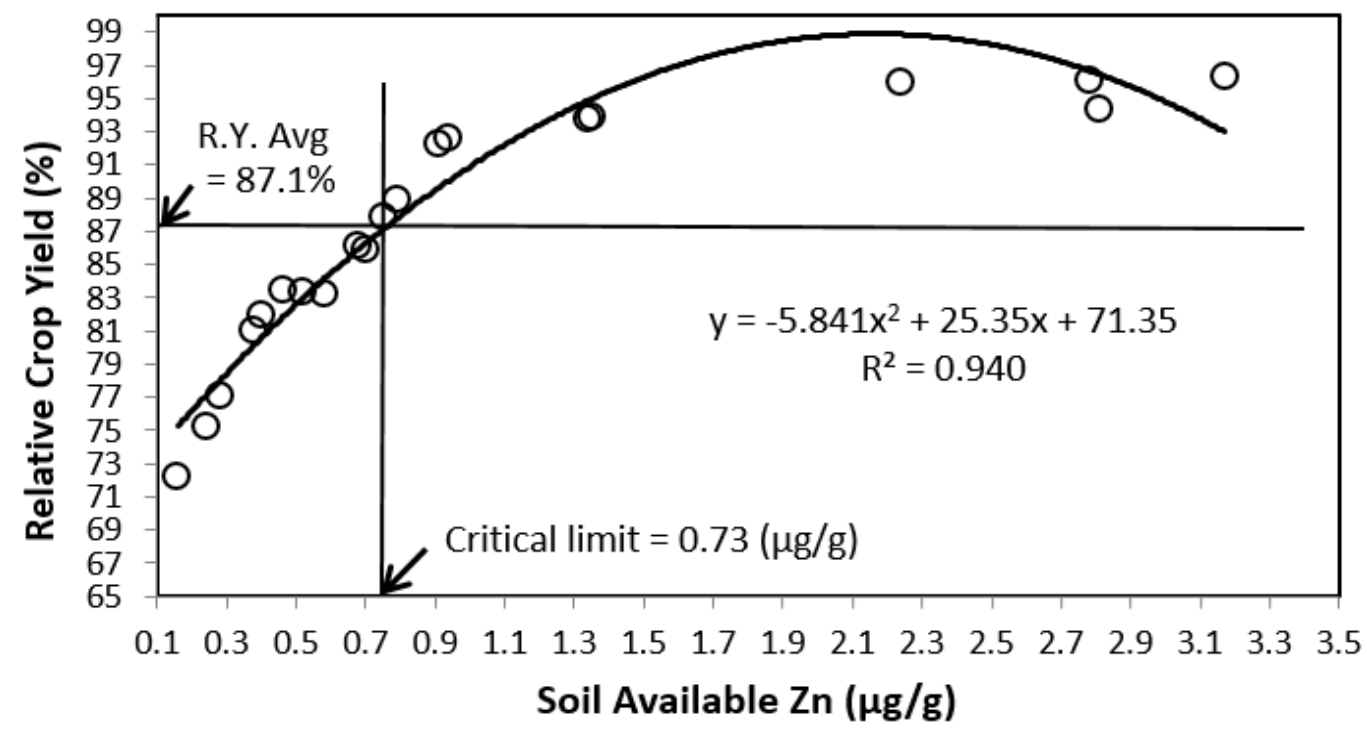

Figure 3. Scatter diagram of available soil Zn vs. Bray's percent dry matter yield of potato.

The data showed that the critical limits of $\mathrm{Zn}$ for potatoes were 26.61 and $27.1 \mu \mathrm{g} / \mathrm{g}$ by statistical and graphical method (Table S4 and Figure 4), respectively. The data suggest that if the plant contains less than $27.1 \mu \mathrm{g} / \mathrm{g} Z \mathrm{n}$, the crop would respond to application of $\mathrm{Zn}$, and this critical limit is important for predicting the sufficiency and deficiency level of $\mathrm{Zn}$ in plants.

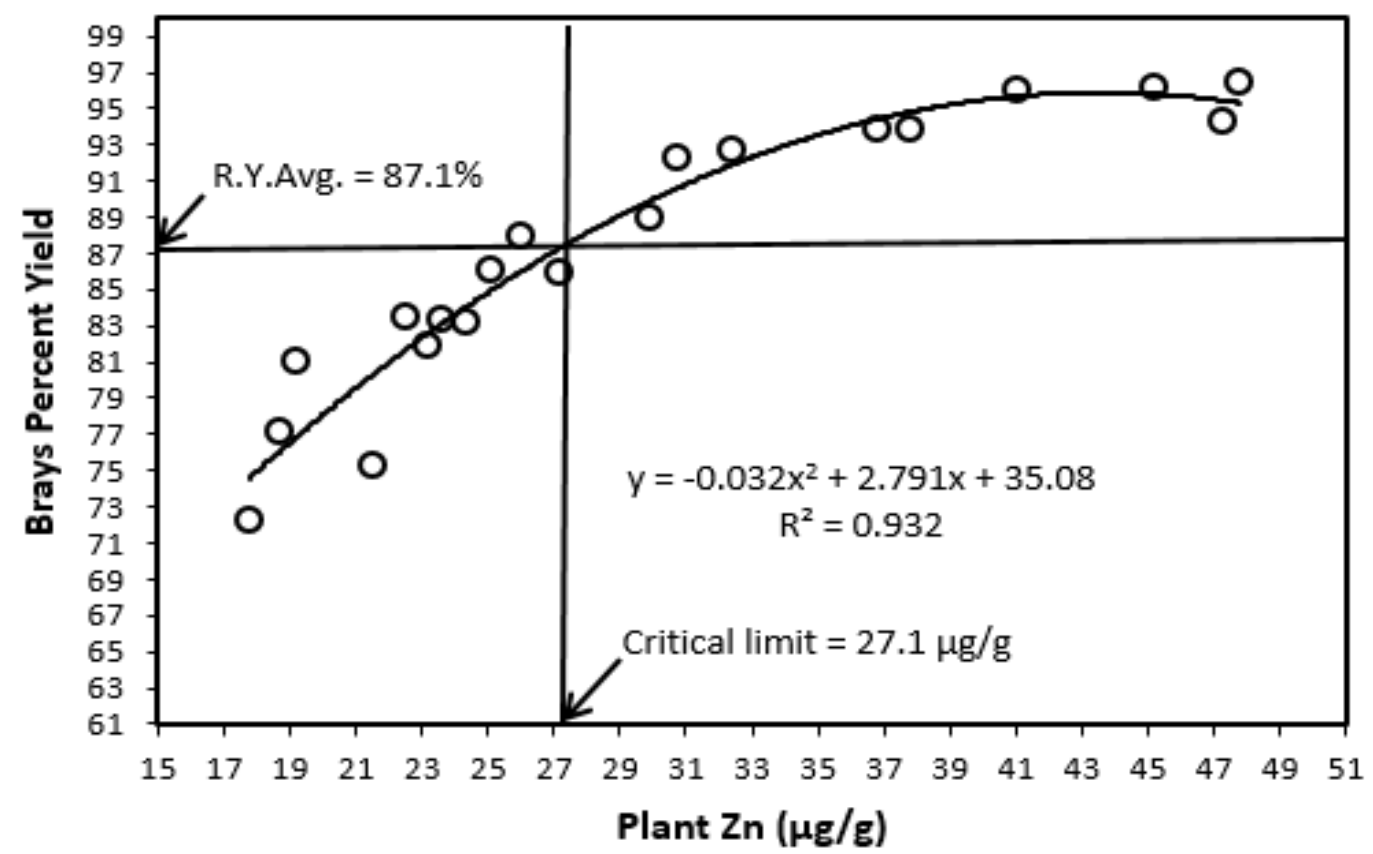

Figure 4. Scatter diagram of Zn concentration in plant vs. Bray's percent dry matter yield of potato. 


\section{Discussion}

A set of 20 representative soils were selected from 720 soils throughout Bangladesh covering two AEZs (AEZ-9 and AEZ-10), having a wide range in texture, general soil type, cropping pattern and land type. The soils were dominated by rice-based cropping patterns and belong to subtropical monsoon climates with a wide variation in rainfall patterns, temperature and humidity. Rice is predominately grown in AEZ-9 and potatoes in AEZ-10 [7]. The soil analysis revealed that the soil's Zn concentration and other physicochemical parameters varied significantly, since the soil samples were collected from different parts of Bangladesh. The varied critical value of $\mathrm{Zn}$ for rice and potato [7] could be due to the diversified sample approach. Murthy [20], who also highlighted that a change in sample sites causes significant variation in nutrient $\mathrm{CL}$, corroborated this idea.

Based on this present study, the CL for $\mathrm{Zn}$ in soil for rice and potato increased compared to the previous values. The critical limit of available $\mathrm{Zn}$ for rice in the present study was $0.80 \mu \mathrm{g} / \mathrm{g}$ and $0.85 \mu \mathrm{g} / \mathrm{g}$ in graphical and statistical methods, respectively. For potato, it was $0.73 \mu \mathrm{g} / \mathrm{g}$ in both methods. These values are close to a critical level for $\mathrm{Zn}$, as observed by other authors [21-25]. The previously observed CL of $\mathrm{Zn}$ for rice and potato was $0.6 \mu \mathrm{g} / \mathrm{g}$, which is lower than the present study findings. It is expected that rice crops will respond to $\mathrm{Zn}$ application when the soils contain less than $0.80 \mu \mathrm{g} / \mathrm{g}$ and $0.85 \mu \mathrm{g} / \mathrm{g} \mathrm{Zn}$ content, and the potato will respond when the $\mathrm{Zn}$ concentration in soil is $0.73 \mu \mathrm{g} / \mathrm{g}$. This increase in $\mathrm{CL}$ for $\mathrm{Zn}$ might occur due to the intensive cropping system, limited application of $\mathrm{Zn}$ fertilizer and high soil $\mathrm{pH}$, favoring enhanced $\mathrm{Zn}$ adsorption and precipitation in soil [26]. Instead of using soil test data, the CL for $\mathrm{Zn}$ in plant tissues can also be utilized as an indicator to assess the requirement of $\mathrm{Zn}$ application. Based on the present study, the tissue $\mathrm{Zn}$ concentration was $23.9 \mu \mathrm{g} / \mathrm{g}$ and $24.32 \mu \mathrm{g} / \mathrm{g}$ for rice and $27.1 \mu \mathrm{g} / \mathrm{g}$ and $26.61 \mu \mathrm{g} / \mathrm{g}$ for potato by graphical and statistical methods, which is also in agreement with Dudde and Maleware [27]. Thus, anyone can determine the requirement of $\mathrm{Zn}$ by assessing the CL both for soil and plant tissue concentrations.

The CL of a nutrient in soil may vary depending on crops, soil, and extraction methods. $\mathrm{Zn}$ availability in soil depends on the soil type (Zn deficiency occurs most often in sandy soil), soil $\mathrm{pH}$ (available at a low soil $\mathrm{pH}$ ) and organic matter content in soils. Thus, it is essential to determine and update the CL for $\mathrm{Zn}$ to formulate an appropriate dose of deficient nutrients for various crops and soils. Due to current agricultural practices, the $\mathrm{CL}$ will continue to change, and constant monitoring is required to maximize fertilizer use efficiency and maintain a sustainable production system. Due to the available soil $\mathrm{Zn}$ corresponding to a corrected sum of squares for the population in this study to determine the predictability value, a lower value in the statistical technique might arise $\left(R^{2}\right)$. However, this dispute requires further investigation to know why the CL is lower in the statistical method than the graphical method. It was already reported that the statistical approach for determining CL provides a lower value than the graphical approach [28]. Researchers can use any method to determine the CL of nutrients in the soil because the CL values are similar in both methods. Because a more significant percentage of soils will fail to comply with the $\mathrm{CL}$, we propose utilizing the maximum critical value calculated from the graphical and statistical approach to assure increased crop output. A competent approach should be able to forecast the amount of plant-available nutrients and the fertilizer responsiveness of crops grown in a variety of soils. In this regard, determining CL via two different methodologies is imperative in determining the optimum fertilizer demand [28].

Applying Zn to soil significantly improved the dry shoot biomass of crops cultivated in various soils. The increase was higher in low-Zn-containing soils than high-Zn-containing soils. The application of $\mathrm{Zn}$ to soil exhibited approximately a $10 \%$ increase in dry shoot biomass compared to when no Zn was applied to soil [29]. Naik and Das [30] reported that the application of $\mathrm{Zn}$ to low land rice soil resulted in the $37.8 \%$ and $20.9 \%$, the most significant increase in the grain and straw yield of rice, respectively, over the control. Soils with a low $\mathrm{Zn}$ content gave a maximum response to tuber yield and increased potato yield by $8 \%$ [31]. Dry matter accumulation is a crucial crop growth metric that is often used 
to calculate the economic returns influenced by the effects of various treatments. In crop ecosystems, $\mathrm{Zn}$ is frequently a limiting element for shoot biomass yield [32]. The efficient uptake and metabolism of available $\mathrm{Zn}$ might contribute to the gains in shoot biomass output seen in this study, which is also in agreement with Rashid and Fox [33]. Thus, applying $\mathrm{Zn}$ to the soil at or above the CL will aid in crop development and productivity in various soil types.

\section{Conclusions}

We conclude that $\mathrm{Zn}$ significantly increased shoot dry matter yield in rice and potato. Overall, the additional Zn supply should provide a yield benefit in a soil with a Zn content of less than $1 \mu \mathrm{g} / \mathrm{g}$. To be specific, the CL of available $\mathrm{Zn}$ for soil in rice was $0.8 \mu \mathrm{g} / \mathrm{g}$ and $0.85 \mu \mathrm{g} / \mathrm{g}$ in graphical and statistical methods, respectively, below which there is a strong probability of observing a successful response to the added $\mathrm{Zn}$ fertilizer. In both methods, the CL for potato was $0.73 \mu \mathrm{g} / \mathrm{g}$, which was higher than the present CL $(0.6 \mu \mathrm{g} / \mathrm{g}$ soil). The critical plant tissue concentration of Zn was $23.9 \mu \mathrm{g} / \mathrm{g}$ and $24.32 \mu \mathrm{g} / \mathrm{g}$ for rice, and $27.1 \mu \mathrm{g} / \mathrm{g}$ and $26.61 \mu \mathrm{g} / \mathrm{g}$ for potato by graphical and statistical methods, respectively. The findings from this study can be used for updating fertilizer recommendation guides for efficient fertilizer applications in Bangladesh. This study may also ensure that $\mathrm{Zn}$ fertilization is crucial for achieving a higher economic yield of rice and potato and sustainable soil Zn management below the specified level. However, future research should confirm the current study's findings in actual field conditions.

Supplementary Materials: The following are available online at https:/ /www.mdpi.com/article/10.3390/ su14010167/s1, Table S1: Critical limit of soil available Zn for rice by statistical method; Table S2: Critical limit of plant Zn for rice by statistical method; Table S3: Critical limit of soil available Zn for potato by statistical method; Table S4: Critical limit of plant Zn for potato by statistical method.

Author Contributions: Conceptualization and experimental design, M.A.A., M.M.R.J. and M.H. (Mahmud Hossain); research and data collection, M.R.; data analysis, M.A.A. and M.R.; writingoriginal draft, M.R.; writing—reviewing and editing, M.G.K., M.H. (Md Hosenuzzaman) and Z.M.S.; supervision, M.A.A. All authors have read and agreed to the published version of the manuscript.

Funding: The authors acknowledge the financial support from the World-Bank-funded NATP-Phase II (Project ID: P149553) and the Government of Bangladesh.

Institutional Review Board Statement: Not applicable.

Informed Consent Statement: Not applicable.

Data Availability Statement: The data are available from the corresponding author upon reasonable request.

Acknowledgments: The first author gratefully acknowledges the financial support from the World Bank and the logistic support from the Department of Soil Science, Bangladesh Agricultural University in collecting soil and conducting experiments.

Conflicts of Interest: The authors declare no conflict of interest.

\section{References}

1. Fageria, N.K.; Baligar, V.C.; Clark, R.B. Micronutrients in crop production. Adv. Agron. 2002, 77, 185-268.

2. Das, D.K. Micronutrients: Their Behavior in Soils and Plants; Kalyani Publishers: New Delhi, India, 2003.

3. Singh, K. Determination of critical limit of zinc in rice soils in India for predicting response of rice to zinc application. Field Crops Res. 1984, 9, 143-149. [CrossRef]

4. Rattan, R.K.; Patel, K.P.; Manjaiah, K.M.; Datta, S.P. Micronutrients in soil, plant animal and human health. J. Indian Soc. Soil. Sci. 2009, 57, 546-558.

5. IRRI. Annual Report for 1977. P.O. Box-933; IRRI: Manila, Philippines, 1978.

6. Shah, A.L.; Rahman, M.S.; Aziz, M.A. Outlook for fertilizer consumption and food production in Bangladesh. Bangladesh J. Agric. Environ. 2008, 4, 9-26.

7. SRDI. Land and Soil Statistical Appraisal Book of Bangladesh; Soil Resource Development Institute, Farmgate: Dhaka, Bangladesh, 2010.

8. Prasad, R.; Prasad, L.C.; Agrawal, R.K. Genetic diversity in Indian germplasm of aromatic rice. ORYZA-Int. J. Rice 2010, 46, 197-201. 
9. Parthipan, T.; Ravi, V. Productivity of transplanted rice as influenced by weed control methods. Afr. J. Agric. Res. 2016, 11, 1445-1449.

10. Flis, B.; Zimnoch-Guzowska, E.; Mankwski, D. Correlations among yield, taste, tuber characteristics and mineral contents of potato cultivars grown at different growing conditions. J. Agric. Sci. 2012, 4, 197-207. [CrossRef]

11. White, P.J.; Bradshaw, J.E.; Dale, M.F.B.; Ramsay, G. Relationship between yield and mineral concentrations in potato tubers. HortScience 2009, 44, 6-11. [CrossRef]

12. Blagoeva, V.; Iliev, E.; Nikolova, E. Potatoes-Growing, Diseases and Enemies, Storage; The Publishing House: Westminster, CO, USA, 2004; p. 105.

13. Ulrich, A. Plant analysis in sugar beet nutrition. In Plant Analysis and Fertilizer Problems; American Institute of Biological Science: Washington, DC, USA, 1959; pp. 190-211.

14. Smith, P.F. Mineral analysis of plant tissues. Ann. Rev. Plant Physiol. 1962, 13, 81-108. [CrossRef]

15. Cate, R.B.; Nelson, L.A. Graphical procedure for critical limits of nutrients. Proc. Soil Sci. Soc. Am. 1965, 89, 658.

16. Cate, R.B.; Nelson, L.A. A simple statistical procedure for partitioning soil test correlation data into classes. Proc. Soil Sci. Soc. Am. 1971, 35, 658-659. [CrossRef]

17. Page, A.I.; Miller, R.H.; Keeney, D.R. Methods of Soil Analysis. Part 2, 2nd ed.; American Society of Agronomy Inc.: Madison, WI USA, 1989.

18. Lindsay, W.L.; Norvell, W.A. Development of a DTPA Soil Test for Zinc, Iron, Manganese, and Copper. Soil Sci. Soc. Am. J. 1978, 42, 421-428. [CrossRef]

19. Gomez, K.A.; Gomez, A.A. Statistical Procedures for Agricultural Research, 2nd ed.; John Wiley and Sons: New York, NY, USA, 1984; p. 680.

20. Murthy, I.Y.L.N. Critical nutrient limits in major oil seed crops-A review. Fertil. News 2004, 49, 51-55.

21. Rahman, M.A.; Jahiruddin, M.; Islam, M.R. Critical limit of zinc for rice in calcareous soils. J. Agric. Rural Dev. 2007, 5, 47. [CrossRef]

22. Muthukumararaja, T.; Sriramachandrasekharan, M.V. Critical limit of zinc for rice soils of Veeranam command area, Tamil Nadu, India. ARPN J. Agril. Biol. Sci. 2012, 7, 22-33.

23. Gangwar, M.S.; Chandra, S.K. Estimation of critical limit for zinc in rice soils. Commun. Soil Sci. Plant Anal. 1975, 6, 641-654. [CrossRef]

24. Kumari, M.; Yadav, K.; Nisha, K. Critical limits of zinc in soil and plants for maize in Diaraland soils of Bihar. Environ. Ecol. 2013, 31, 1107-1110.

25. Sakal, R.; Singh, A.P.; Singh, B.P.; Sinha, R.B. Assessment of some chemical extractants for available zinc in relation to response of rice to applied zinc in Sub-Himalayan Hill and forest soils. Plant Soil. 1984, 79, 417-428. [CrossRef]

26. Kuldeep, S. The Critical Zinc Deficiency Levels in Indian Soils and Cereal Crops. UC Davis: Department of Plant Sciences. 2009. Available online: https:/ / escholarship.org/uc/item/4h0788h5 (accessed on 14 November 2021).

27. Dudde, K.B.; Maleware, G.U. Soil test and plant analysis for diagnosing zinc deficiency in groundnut and mung. Ann. Plant Physiol. 2005, 19, 75-79.

28. Yesmin, R.; Hossain, M.; Kibria, M.G.; Jahiruddin, M.; Solaiman, Z.M.; Bokhtiar, S.M.; Hossain, M.B.; Satter, M.A.; Abedin, M.A Evaluation of Critical Limit of Sulphur in Soils for Wheat (Triticum aestivum L.) and Mustard (Brassica napus L.). Sustainability 2021, 13, 8325. [CrossRef]

29. Farzana, S.; Sarkar, A.; Hosenuzzaman, M.; Galib, M.A.A.; Hoque, M.A. Effects of zinc on growth and yield of rice cv. BRRI dhan29 under alternate wetting and drying water management practice. J. Food Agric. Environ. 2021, 2, 25-30. [CrossRef]

30. Naik, S.K.; Das, D.K. Evaluation of various zinc extractants in low land rice soil under the influence of zinc sulphate and chelated zinc. Commun. Soil. Sci. Plant Anal. 2010, 41, 122-134. [CrossRef]

31. Mahata, M.K.; Debnath, P.; Ghosh, S.K. Critical limits of zinc in soil and rice plant grown in alluvial soils of West Bengal, India SAARC J. Agric 2012, 10, 137-146. [CrossRef]

32. Pareek, F.; Ghazanchi, R. Study of the effect of chemical fertilizers, compost and their combination on Aloe vera growth and yield. Sci. Res. 2012, 5, 64-66

33. Rashid, A.; Fox, R.L. Evaluating internal zinc requirements of grain crops by seed analysis. Agron. J. 1992, 84, 469-474. [CrossRef] 